10 years ESJ

Special edition

\title{
Pitirim Sorokin and COVID-19
}

\author{
David Wilkinson
}

University of California, Los Angeles (UCLA), United States

Doi: $10.19044 /$ esj.2021.v17n31p1

Submitted: 01 May 2021

Accepted: 02 August 2021

Published: 15 September 2021
Copyright 2021 Author(s)

Under Creative Commons BY-NC-ND

4.0 OPEN ACCESS

Academic Editors: Georgios Farantos \& Nikitas-Spiros Koutsoukis

Cite As:

Wilkinson D. (2021). Pitirim Sorokin and COVID-19. European Scientific Journal, ESJ, 17

(31), 1. https://doi.org/10.19044/esj.2021.v17n31p1

\section{Abstract}

In 1942, the sociologist Pitirim Sorokin, a survivor of the post-WorldWar I pandemic, published "Man and Society in Calamity," a comparative study of the human response (including political responses) to four recurrent mass-death events. One was "pestilence." Sorokin reached many general conclusions. In Fall of 2020, the author of this paper (Wilkinson) held a seminar whose students attempted to re-evaluate Sorokin's conclusions, based upon their own experiences, observations, and mutual dialogue. In general, the seminar found that Sorokin's conclusions were mostly still applicable, but that his social theory of pestilence needed drastic changes as concerned (a) the gendered, class-based, ethnic and national distribution of pestilence and its consequences of pestilence, (b) the much-changed capacity (from 1942) for the scientific and technological response to pestilence, and (c) the much changed capacity (again, since 1942) for international-organizational response to pestilence. With these updates, Sorokin's theory of the human social response to pestilence can serve as guidance both for study and for policy in regard not only to the current pandemic, but for epidemics and pandemics yet to come.

Keywords: Pandemics, COVID-19, Pitirim Sorokin 


\section{Introduction}

As this article is written (July 22, 2021), there have been nearly 193 million cases of COVID-19 and more than 4 million deaths. (https://www.worldometers.info/coronavirus/)

Almost 80 years ago, the great sociologist and civilizationists Pitirim Sorokin attempted to construct a general theory of "pestilence." We shall examine the current COVID "pestilence" and consider the applicability to it of Sorokin's mid-20oth-century thoughts.

The COVID-19 pandemic began in late 2019, and spread very quickly. In December or late November of 2019, an outbreak of a viral pneumonia later labeled COVID-19 occurred in Wuhan, China. Illnesses and deaths multiplied, first at staggeringly high rates (4 days to 18 days to double, during JanuaryMay 2020).

By May 2020, the disease was essentially under control in China, after rigorous travel bans and quarantines/isolation measures. Elsewhere, however, there was less effective control, with consequences. To speak logarithmically, as must be done in conditions (to begin with) of exponential growth, the first global death was posted in January 2020, likewise the first ten and first 100; the first 1000 in February; the first 10,000 in March; the first 100,000 in April. With the establishment of control in China, the rate of growth and doubling time then slowed markedly. The first million deaths were not reported in May, as might have been expected, and the tenth million did not occur in June and has not occurred after more than a year. Instead, the first million deaths were not reported until September 2020, the second million in January 2021, the third million in April 2021, the fourth million in July 2021.. Linear, and not exponential, models of growth have become dominant. These may reflect both improved control and some degree of "burnthrough" toward herd immunity.

The slowdown however is real, and is probably best comprehended via the death count doubling times: doubling times for deaths have notably increased, to from the horrific days of Winter and Spring 2020 to the more comprehensible, if no less unpleasant and undesirable, 130 days in April 2021. There are other persuasive signs of improved control: the death outcome of cases has fallen dramatically, from over 40\% in February 2020 to 2\% in July 2021.

However, like many epidemic predecessors, COVID-19 infections and deaths have also come in waves. The first wave of deaths peaked in April, 2020, the second in August 2020, the third in January 2021, the fourth in May 2021; a fifth wave appears to be rising as I write (July 22, 2021).

The waves have also reflected a shift in pandemic "hot spots": China, then the Unites States, then India, then multiple, shifting sites. This shift from country to country is a sign of failed national and global control. As measured 
by case growth rates, China clearly lost control in January 2020, but had managed to restore it by April of that year. The United States lost control in October 2020, had notably improved by February 2021, and now shows signs of backsliding. India lost control in March 2021 but had regained it by June 2021..

There may be other such nation-level losses of control in germination. As of this writing, several countries-France, Vietnam, Senegal, Italy, the Isle of Man - are showing case rates in the thousands and weekly case growth rates of $100 \%$ or above. But to offset this development, several effective vaccines have been developed, and some countries have surpluses which they have undertaken to export or share. Sri Lanka and Nepal, growing explosively in April 2021, had slowed case growth noticeably as of July.

It cannot be said that the COVID pandemic is under control; it is far from ended, and no end-time can be predicted; but means of control have been and are being developed, always with delays and lags. It now seems possible to begin to inspect COVID-19 reflectively, in wider contexts. Both new perspectives and marginalized perspectives might provide insights. This article will attempt one such contextualization, via a focus on of the work of a Russo-American sociologist who flourished in the middle of the $20^{\text {th }}$ century, and on 2020 student critiques of his work.

The sociologist was Pitirim Alexandrovich Sorokin (January 21, 1889 - February 10, 1968). In his life, Pitirim Sorokin was variously a starving peasant orphan, itinerant church painter and icon-embellisher, self-taught bookworm, empirical penologist, Socialist Revolutionary political activist, three-time political prisoner under Tsar Nicholas II, a secretary to the shortterm Russian Prime Minister Alexander Kerensky, three-time political prisoner under the rule of V.I. Lenin, starving intellectual worker, fellow-exile (but onshore, by train) of the "Philosophy Steamer" (or "Ship of Expelled Russian Thinkers"), quantitative-positivistic sociologist, founding father of sociology in both Russia and the United States (where he both brought sociology to Harvard University), and co-founder of the International Society for the Comparative Study of Civilizations.

Sorokin's intellectual journey led him to describe himself as a "conservative Christian anarchist" after the fashion of Henry Adams, and to declare as a Tolstoyan believer that "the Kingdom of God is within you." After being rendered unfashionable at Harvard, perhaps by his zealous combativeness on intellectual issues Sorokin rose again as a successful writein candidate for President of the American Sociological Association (serving in 1965). He wrote many volumes. One of these volumes features in this paper.

During World War II (in 1942, to be precise), Sorokin wrote Man and Society in Calamity, a broad-ranging summary of the chief features of four 
recurring human "calamities," occurrences which produced massive death tolls: war, revolution, pestilence and famine. He considered all to be species of the same genus, with not only interconnections, but shared underlying causes. Therefore he examined them as a matched set. In Man and Society in Calamity, Sorokin gave an extremely brief overview of the artistic, behavioral, cultural, economic, ethical, ideological, political, psychological, religious, scientific, sociological, and technological aspects of calamities; and he proposed, again, an extremely brief view of their causes, remedies, and future. The part and chapter heads below will indicate the breadth of the study.

PART ONE: THE INFLUENCE OF CALAMITIES UPON OUR MIND chapter I How Calamities Influence Our Affective and Emotional Life chapter II How Calamities Affect Our Cognitive Processes, Desires, and Volitions

\section{PART TWO: THE INFLUENCE OF CALAMITIES UPON OUR BEHAVIOR AND VITAL PROCESSES chapter III How Famine Influences Our Behavior} chapter IV How Pestilence, War, and Revolution Influence Our Behavior chapter V How Calamities Influence the Vital Processes: Death, Birth, and Marriage Rates and Social Selection

\section{PART THREE: THE INFLUENCE OF CALAMITIES UPON SOCIAL MOBILITY AND ORGANIZATION \\ chapter VI Migration, Mobility, and Disruption of Social Institutions chapter VII The Influence of Calamities upon Political, Economic, and Social Organization chapter VIII The Influence of Calamities upon the Economic Standard of Living}

\section{PART FOUR: THE INFLUENCE OF CALAMITIES UPON SOCIOCULTURAL LIFE}

chapter IX Two General Effects of Calamities upon Sociocultural Life chapter X How Calamities Affect the Religious and Ethical Life of Society chapter XI Calamities and Ethico-Religious Process chapter XII Sinners and Saints in Calamity chapter XIII The Influence of Calamities upon Science and Technology chapter XIV Influence of Calamities upon the Fine Arts chapter XV Dynamics of Ideologies in Calamity 


\section{PART FIVE: CAUSES AND REMEDIES OF CALAMITIES chapter XVI Causes of Calamities chapter XVII The Way Out of Calamity chapter XVIII A Glance Into the Future}

Sorokin had personal experience of each "calamity": war (World War I); revolution (Russian Revolution); famine (Soviet famine 1921-1922; and pestilence (more as typhus in Russia-0-2 to 3 million dead-- than as the local manifestation of the global influenza pandemic). And in Russia they were very clearly interconnected. Defeat in war evoked revolution; socio-economic breakdown in revolutionary civil war led to famine; troops, prisoners, and physicians fell to typhus. The unity of these calamities is reflected in the difficulty of allocating fatalities as among them.

All four of Sorokin's calamities are enduring presences in the world of 2021. In this world, war and revolution (the latter mostly in the form of state collapses into civil war) are inseparable fellow travelers, in Afghanistan, Yemen and Ethiopia, to name only the largest of dozens of conflicts that have created hundreds to hundreds of thousands of direct, violent killings. Tens of millions are in need of emergency food assistance each year, and the number has recently increases steadily, with the above-named countries plus the Democratic Republic of Congo, Sudan, South Sudan, and Nigeria specifically cited.

And COVID-19 s an exemplary "pestilence." COVID-19 (in its youth labeled SARS-Cov-2) has joined the Antonine Plague (AD 165-180), the Plague of Cyprian (AD 249-262), the recurrent Two Centuries Justinianic Plague (AD 541-549, first round; aftershocks, 15 rounds AD 541-750), the Black Death (AD 1346-1353), the Third Plague Pandemic in China and India, (main shock from 1855, with afterwaves to 1960). We note also the smallpox epidemics that depopulated the New World and took down Amazonian and Mississippian Civilizations; and we may add the 337 epidemic years in Chinese historical records ( $\mathrm{Li}, 2004)$.

This world of interminable war, failed states, food emergencies and pandemic is not the world intended and partly built by the victor nations of World War II. The victor states engaged in what was then called "post-war planning," and established international institutions and practices precisely intended to limit or prevent "calamities." Epidemics, famines, wars and revolutions, all had separate institutions and practices created and directed at their limitation, reduction, or abolition: large military alliances with nuclear deterrents and the United Nations Security Council vs. the war disaster; the World Bank and the International Monetary Fund, built on the theory that economic development and stabilized prosperity were preventers of state failure and collapse; the Food and Agricultural Organization and the World 
Food Programme for global progress against hunger and famine; and the World Health Organization against pestilence.

It cannot be said that these international institutions have truly failed that, so that, like the League of Nations, predecessor to the United Nations, they should be scrapped and replaced, or their undertakings abandoned. But it also cannot be said that they are so markedly successful that no reforms nor improvements should be considered. Interminable wars (Afghanistan, Yemen, etc.), "fragile states" (aka "failed states"), severe food crises, epidemics and pandemics, show no signs of departure from history. The COVID-19 pandemic is only the currently most visible member of this class of mass death event. Let us focus on that class and that member for now.

WHO, the World Health Organization, an international institution, a specialized agency of the United Nations responsible for international public health, was founded in 1948, with 149 member states. Again, it is no failure. WHO has had signal success in fighting endemic and epidemic diseases such as smallpox, tuberculosis, malaria, guinea worm, HIV/AIDS (pandemic from the 1980s), Ebola virus (epidemic 2013-2016), Zika virus epidemic (20152016), and others.

It was, however, notably unsuccessful in its early efforts against COVID-19, and not at all because of inattention or negligence. WHO was alerted fairly quickly. On 31 Dec 2019 WHO's Country Office in the People's Republic of China picked up a media statement by the Wuhan Municipal Health Commission from their website on cases of 'viral pneumonia' in Wuhan, People's Republic of China."

(https://www.who.int/emergencies/diseases/novel-coronavirus-

2019/interactive-timeline\#, accessed 4-29-2021) Data were soon being published, and it was possible to trace the spread of the pandemic-to-be from its origin.

Mortality and morbidity data (e.g. from Johns Hopkins University's Center for Systems Science and Engineering) were soon widely available. The first mortality was cited as of January 22, in Wuhan. As of noon January 23 EST, there were at least 18 dead and more than 650 people around the world afflicted, with the majority of cases in mainland China, with 639 ill. Johns Hopkins' map of that date showed over 30 different sites, most in China, where cases had already been reported. This early dispersal, likely mediated by air and high-speed rail travel, helps to define the novel character of the disease, which was indeed to become a pandemic.

The US CDC (Center for Disease Control) addressed the issue. ""We understand that many people in the Unites States are worried about this virus," said Dr. Nancy Messonnier, director of the National Center for Immunization and Respiratory Diseases (part of the Centers for Disease Control and Prevention). 
"At this time, in the U.S., the virus is not spreading in the community," she added. "For that reason we continue to believe that the immediate health risk from the new virus to the general public is low at this time."

Story is January 27, 2020 (https://abcnews.go.com/Health/coronavirusspreading-us-cdc/story?id=68560892, accessed January 28,2020 )

By January 28, what was then styled "2019 nCov2" had confirmed cases in 19 countries, the vast majority being found in mainland China. (https://www.afp.com/sites/default/files/nfs/diffintra/english/shared/top/fa13bd9af9968cc282ae93f3c85277bd8eb64468.jpg, accessed 1-28-2020)

As of 4 February, 2020, however, the death toll had risen to 427 , the morbidity to 20,626. Confirmed cases were reported on 4 continents and in 26 countries. (https://www.ecdc.europa.eu/en/geographical-distribution-2019ncov-cases, accessed 4 February 2020)

And the pandemic continued to spread, by July 2021 having reached $100 \%$ of 222 countries and separate reporting territories in the world. Again, total institutional failure this is not; COVID-19 is an exception, if a glaring one, and most human illnesses attacked by international institutions have yielded or at least been held at bay. The past of COVID-19 is now fixed, the present unstable, the future indeterminate. But new or revised thinking with a long perspective does seem to be in order, or at least worthy of serious consideration.

\section{ORIGIN OF THIS STUDY}

While in some countries and cultures new challenges are remanded to the attention of elders, religious or specialists, the United States of America has a somewhat variant culture. There tends to be a search for novelty, and voice is given to the younger.

As a participant I $n$ that culture, and with access to an eager and informed generation of students, not just Americans, I embarked upon an inquiry. By the Fiat Lux program of UCLA, which sought new ideas on COVID, it was possible to invite some serious thinking among thoughtful members of the rising but still unempowered generation. The likewise variant ideas of Pitirim Sorokin might be used, I thought, to discern new patterns and to provoke new thought.

The course I here report, UCLA Political Science 19-1, Fall 2020, enrolled 9 students, each of whom weekly read (online) and commented on one or more chapters of Calamity, and then commented on a classmate's prior week chapter-appraisal, except that in the last week each reappraised the entire volume. They were to discuss whether Sorokin's assertions of nearly 80 years past did or did not fit COVID-19 pandemic as they has experienced it, observed it newswise, and discussed it; and to propose amendments where they saw errors or new data. 
Many voices were heard. Students cited their ethnic heritages (e.g. Russian, Chinese, Armenian....) and reflected their own marked individualities. But where there were commonalities, I have cited them below.

Emotional instability. For Sorokin, calamities call forth emotional intensity and emotional instability in general. In particular, with respect to pestilence: Sorokin contends that pestilence imposes psychological isolation and "social death" upon its victims, increasing the tendency to suicide, and disturbs the emotional life of all those close to the victims. In their psychological isolation, people are parted from others who are not affected by the calamity, and they are in a sense rendered totally alone in their relationships and in their suffering.

Seminar: Sorokin's generalizations were thought to have extended well beyond the sickhouse. Quarantines, lockdowns, and travel bans imposed widespread and painful psychological isolation and a degree of "social death" wherever they were experienced. But there were important offsets, by way of equally widespread technologies not available in 1942: monologic (24/7 video and online news) and dialogic (cellphone, email, Zoom) communications.

Monopolization of attention. Sorokin argues that calamities in general tend to monopolize our attention, so that we put everything else on the back burner, or shove it aside.

Seminar: Sorokin was seen as only partly correct for the COVID pandemic. COVID-19 did consume attention, probably more so than previous epidemics and pandemics, precisely because of the same technological advancements that mitigated psychological isolation. But the slowdown in the spread of the pandemic after the first disastrous months allowed some social and media-watching attention to be diverted to nonpandemic matters.

Intellectual disruption. Sorokin: calamities tend to weaken and disorganize our mental activities.

Seminar: "science denial" was mentioned as a source of widely observed disregard for masking and social distancing. Science denial could also today prove a source of vaccine refusal, noticed as of this writing, when vaccines have become more available. Progress toward "herd immunity" could be undermined by such science denial and vaccine refusal.

Birth, marriage and divorce. Sorokin asserts that calamities lower both birth rates and marriage rates, as people postpone new commitments to await a (possibly) brighter future. 
Seminar: this matched experience statistics had not yet been noticed. An important addendum, consistent with Sorokin's more general note that calamities are also destructive of families, was the observation of rising divorce rates

Unequal social distribution of death. Sorokin also discusses the unequal distribution of deaths in calamity-afflicted society: Who dies? Who survives?

Seminar: wealth, social status, and remote work were seen as advantageous to survival. The elderly, frontline workers, and people living or working in crowded conditions were disadvantaged.

Migration, mobility and disruption of social institutions. Here Sorokin argues that calamities affect social mobility: horizontally, in the form of exodus and migration; vertically, in the form of rise and fall of status, and also, simply, disruptively. In pestilence, particularly, people flee from the affected area, and also from cities to the countryside. In the exodus, children, the elderly, the "weak" and the sick tend to become fatalities. In calamities generally, people gain and lose status at a higher rate of speed than in normal times: vertical mobility, the "circulation of elites," accelerates. And families and institutions are disrupted by calamity, offering the opportunity for new social forms to emerge

Seminar: some COVID-19 flight from pandemic centers was noticed, but was seen as quickly and tightly constrained by lockdowns, travel bans, and quarantines. Exodus fatalities were seen as both avoidable and avoided in the more limited exodus of COVID-19. Very substantial downward mobility was seen, mostly loss of status and work, but not much gain of status. Persons of high social rank were better able to defend their lives, health, property and status than those already living on the edge. Loss of social ties, including family dissolution, was also much noticed, but not the development of new social ties, except via media.

State regulation. Sorokin argues that all calamities lead to an increase in governmental regulation and control, even to the point of totalitarianism, and that this course only reverses after the calamity has passed away.

Seminar: an increase in regulation, definitely; totalitarianism, less so. But the early success of rigorous control measures in China, contrasted with the loss of control in the United States, was seen as a benefit of competent autocracy, and derogatory to the value of individual freedom.

Living standards. Sorokin argues that, while calamities in general increase economic misery, war and revolution in particular diminish economic 
class inequality, while all calamities shift wealth as between groups: many become poor but some become rich.

Seminar: in the absence of widespread property destruction and violent class conflict under COVID-19, no diminution in class inequality was observed, rather an increase; "many become poor but some become rich" was validated by experience and observation: the new-technology corporations and the few techno-ultrarich were seen as especially having flourished and profited.

Culture change. Sorokin asserts (156) that "Calamity molds an entire culture in its own image" - everything becomes about that thing. His examples in this chapter, however, draw mainly upon the calamity of famine.

Seminar: this effect on culture, as upon the psychology of attention cited above, was seen as present to a degree, but not to the asserted extreme, probably because of COVID-19's lesser demographic impact than the Athenian Plague (430-426 BC) for that city-state, or the Black Death for Europe.

Dynamics of ideology. Sorokin argues that calamities-and their terminations - dramatically alter the popularity of and toleration for select extreme ideologies. In particular, he mentions as influenced by calamity the social valuation of Communism and Socialism, Pacifism and Militarism, and Totalitarianism and Liberty.

Seminar: such ideological change was not seen with COVID-19. Rather, the extant valuation of Socialism was seen as buttressed in China, but Socialism not upvalued elsewhere. No change was seen in the Militarism/Pacifism balance. Totalitarian values were not valorized, though it was judged that many accepted the need for a temporary and provisional obedience to public masking and distancing regulations. Those who valued Liberty became somewhat more ostentatious in their defiance of control, including collective defiance of socialdistancing.

Calamity, science and technology. Sorokin argues that calamities tend to reorder the focus of science and technology upon the calamity itself, so that much more attention is given to the current, the coming, and the evolving character of the calamity, and its causes and cures. He further argues that calamities both stimulate and suppress scientific innovation and scientific progress; and the larger the calamity, the worse the balance of innovation and suppression. Mild calamities tend to produce science and technology directed rationally at their comprehension and cure; extreme calamities, on the other hand, tend to displace science and technology and to promote superstition instead. Pestilence in particular both suppresses progress by killing physicians, 
nurses, other caregivers, students, an onsite observers, and strongly motivates rapid progress in medical and biological, both during the pestilence and immediately afterward: curative research during the pestilence, preventative research thereafter. Students were asked whether they saw both regression to superstition and progress in science as aspects of COVID-19, and what seemed to them to be the net balance between retrogression and progress.

Seminar: thoroughly confirmed. The intense global competition to develop many competing vaccines was seen as a clear sign both of focus and of progress. The relative mildness of the COVID-19 calamity, and the swift progress against it once it became an action focus, was seen as promoting rationality and empiricism. But a reduction in attention to making progress against competing illnesses, e.g. cancer research and diagnosis, was also noticed.

Calamities and the arts. Sorokin argues that calamities temporarily force a regression upon art by driving the arts to focus upon the calamity, and to embody moods of melancholy, pessimism, and even despair. But Sorokin also cites more upbeat influences of calamities upon the fine arts, for example, the promulgation of heroic narratives as model responses to calamity.

Seminar: some melancholia and despair was indeed perceived, but balanced by a significant artistic focus upon effort and hope for the future. "Heroic narratives" glorifying frontline health workers, and workers in "essential" industries, via news photography and spontaneously made and posted videos, were definitely noted, and strongly approved.

Religion and ethics. Sorokin early asserts as a general theme that will recur throughout the book: calamities diversify and polarize societies, and they do so in a multitude of ways. He contends that pestilence specifically polarizes society toward, on the one hand, demoralization and irreligiousness ("Eat, drink, and be merry! For tomorrow we die!"), and on the other hand to moral and religious exaltation.

Seminar: ethical polarization was definitely observed, with hedonism and cynicism at one pole, as with Sorokin, but with science, scientism, and compliance with science-based directives at the other, in place of religiosity.

Interrelation of calamities. Sorokin asserted that war, revolution, famine and pestilence are often interrelated, and that their causal interlinks are important. Sorokin sees pestilence as relatively noncausal to war, revolution and famine, while at the same time it is likely to be a consequence of an y or all. Today, however, others have warned us that COVID19 could be a contributing cause of famine in the world by disrupting global food chains. 
Seminar: COVID-19 was seen as having emerged independently of other calamities, but as likely to harm food distribution to such countries as are both pandemic-stricken and already undernourished.

Supplementary causes. While the infection is the only necessary cause of pestilence, Sorokin mentions a number of additional causes which, if present, supplement the infection and make it more devastating.

Sorokin considered as "supplementary conditions" of pestilence cosmic, biological, climatic and weather factors.

Seminar: none such observed with COVID-19.

Sorokin also cites as a "supplementary" condition of pestilence "intensive commercial or political contact with the places that are the focal points of the infection."

Seminar: now more than ever! The spread of COVID-19 via highspeed rail and air travel outran the management of it, and even the news of it. And ends to quarantining and travel bans will only invite new infections.

Escape from calamity. In Chapter XVII, The Way Out of Calamity, Sorokin contrasts the way in which past calamities have ended with the ways in which they might have been ended by wiser societies, and the ways in which calamities to come might be ended better. As to pestilence, he speaks of "a well disciplined society with an understanding of the necessity of these [curative and preventive] measures and of the value of temporary sacrifice and inconvenience" (299), and of a "wise society" that can both cure the pandemic itself and discern its supplementary causes and attack those as well. It would also integrate scientific knowledge for practice with moral and religious teaching that would ratify its practices. And it would have strong reserves of medical facilities and personnel available for pestilential emergencies.

Seminar: generally approved in principle; US practice seen as very defective in the actual control of COVID-19, due to ignorance, reckless indiscipline, egotism, misinformation, and hoarding, and showing no signs of improvement.

Reconsiderations. The seminar's final question required a reconsideration of Sorokin's theory of pestilence, explicit and implicit, through the entire book. What (if anything) survives unscathed by history? What needs amendment? What needs replacing, and by what?"

Seminar: the prevailing opinion in the class was that most but not all of Sorokin's generalizations applied well to COVID-19, and several students were shocked that, with past pandemic experiences well documented, COVID-19 had nonetheless been allowed to run amok! 
Sorokin's assertion that pestilence induces psychosocial isolation, mental disturbance, obsession, social polarization, technological acceleration, and heroic narratives was ratified.

However, the ideological change expected by Sorokin was not seen; technological change outpaced ethical and religious development; downward social mobility was widespread, upward very restricted; radical social change did not occur; though there was political change in the US 2020 elections, the Chinese government was if anything stabilized.

The overwhelming consensus for revision focused on science and technology. Rapid and extreme advancement since Sorokin wrote has led to substantial mitigation of the size and impact of the pandemic calamity, and to better prospects for the future.

\section{Conclusion}

Limited national focus. Sorokin relied heavily on a study of British epidemic history $(1891,1894)$ by Charles Creighton for his epidemic historical data. And though the ethnic origins of the students surveyed in the UCLA course included India, Armenia and Russia, the experiential and observational work of this study could only be done from its participants' locations, which were (mostly) the United States and China. This experiential bias was somewhat offset by the fact that China and America were also the two sites of the most notable early loss (and uneven restoration) of pandemic control. But COVID-19 appears to have a global future reach, and experiences and observations from India, and from other current sites of control failure (and, hopefully, future restoration), will be highly desirable.

Limited historical focus. Sorokin's work was as transhistorical and transcultural as he could make it under the circumstances of the massive World War II calamity, but there are severe limitations in both regards. Far more work has since 1942 been done on the great past Western pandemics, era by era and disease by disease. And China has historically both collected and lost (in its revolutions) voluminous data. One step forward would be for Chinese researchers to begin with the epidemic-collections of Li Wenbo (2004) and Zhang Zhibin (2007), which are already widely cited by Chinese researchers, but which deserve translation and comparative contemplation. Furthermore, other research by those Chinese researchers suggests an ancient and long-term causal relationship between climatic cycles, famines and violence (Zhang et al., 2007).

Another step forward would be for intellectuals whose cultural backgrounds and research locations are outside the area of Sorokin's familiarity (United States, "Czecho-Slovakia," and the Russian and Komi areas of the former Russian Empire and Soviet Union) to examine Sorokin's 
assertions insofar as they can be examined in their own national/ethnocultural context, but with respect to the impact of COVID-19 upon the societies with which they are most familiar.

Gendered limitations. Sorokin's title, Man and Society in Calamity, would today be queried: an editor would likely suggest Humanity in Calamity. (Scientific American recently searched its past issues to find the rise and fall of scientific terminology in its own pages, and noted with some approval ("socially progressive") that the word "man" had its peak frequency in 1918 and declined thereafter, while the word "human" reached its own peak in 2009, after a steady rise. (Stefaner et al. 2020:33)

However, the word "man" in Sorokin may not be simply translatable into "human." It would be desirable to ask how far the generalities Sorokin proposes are in fact not gender-neutral. More proactively: should there not be a contrasting study of "Woman and Society in Calamity?" While such a study might well face continuing social constraints, today these are unlikely to be as severe as, say, those described by Virginia Woolf in A Room of One's Own (1929) and Three Guineas(1938).

Hypothesis generation. An important, if perhaps undertheorized, part of the scientific process is hypothesis generation. Sorokin's Calamity provides a number of useful hypotheses, testable for COVID-10 in ongoing and (hopefully) retrospective studies via survey research, demographic research, etc. And the student commentaries on Sorokin, especially those which seek to take issue with or to update his generalizations, provide an further hypotheses and counterhypotheses. It is hoped that the study of specific calamities, and even the unifying theory of human calamities to which Sorokin evidently aspired, will be able to profit from this exploratory study.

Intimations of the future. Mostly finding Sorokin's generalization to match their own experience, students spoke well of the relevance of his nearly 80-year-old work. Sorokin's most radical prescription, a global cultural shift from what in some work he called a "sensate" to an "idealistic" culture, and in others from an "egotistic" to an "altruistic" one, was warmly received, but offset by notes on observed recklessly endangering and self-endangering behaviors of peers and others who had decided to ignore or deliberately flout rules of masking and social distancing.

Rather, the major and reiterated source for optimism was reserved for science and technology - and not merely directed technics of medicine and public health, though these were judged very necessary and increasingly hopeful. Credit was spontaneously and in reciprocal comments especially awarded to the unintended or undirected developments in science and technology, and 
specifically not the technology of transportation, which was seen as having contributed to the quick and global spread of the pandemic, but the technology of communication--Internet, email, online education, Zoom, and dialogic social media.

There may have been a halo effect, since the first chapter of Calamity mentions under the head of "Change in Emotions and Affections Induced by Pestilence" the "abrupt psychosocial isolation...social death" of the patient in a pestilence. These students had also felt "abrupt psychosocial isolation" caused by lockdowns, quarantines, travel bans, the end of public events, the shutdowns of accustomed institutions, and they credited social media, monologic as well as dialogic, with the alleviation of this abrupt dissolution of valued social networks. Students found the dissonance between the total isolation described by Sorokin and the partial but remediated isolation of the lockdown society to be the clearest difference between Sorokin's era and their own.

It is certainly possible that the halo effect of their valuation of social media in this regard was led in their reading of later chapters of Calamity into a generalized remedial influence of accelerating development of communications technology, which may not apply so strongly, or perhaps not at all, to the other aspects of the sociology of pestilence mentioned by Sorokin, or to the other three "calamity." And the students' valuation of social media might need to be juxtaposed to their later critiques, also widely shared, of the class distinctions created by the super-richness of the captains of media. But that should be investigated, rather than presumed.

And both liberal institutionalists, who are numerous, and conservative Christian anarchists like Sorokin, who are not, may find that they have to come to grips with a new generation re-formed by an inclination to seek first the technological kingdom!

\section{References:}

1. Creighton, C. $(1891,1894)$ History of Epidemics in England. 2 vols. Cambridge University Press.

2. Doherty, P.C. (2013) Pandemics: What Everyone Needs to Know. Oxford University Press.

3. Li, W. (2004) Zhongguo chuan ran bing shi liao = Historical records of infectious diseases in China. Beijing Shi : Hua xue gong ye chu ban she.

4. McMillen, C.W. (2016) Pandemics: A Very Short Introduction. Oxford University Press.

5. Quinlan, H.E. (2020) Plagues, Pandemics and Viruses: From the Plague of Athens to Covid-19. Visible Ink Press. 
6. Sorokin, P. (1942) Man and Society in Calamity: The Effects of War, Revolution, Famine, Pestilence upon the Human Mind, Behavior, Social Organization and Cultural Life. E.P. Dutton and Company, Inc.

7. Stefaner, M., Daston, L. \& Christiansen, J. (2020) "The Language of Science," Scientific American, 323:3, pp. 27-33.

8. Woolf, V. (1929) A Room of One's Own. New York: The Fountain Press; London : The Hogarth Press.

9. Woolf, V. (1938) Three Guineas. London: The Hogarth Press.

10. Zhibin, Zh. (2007) Zhongguo gu dai yi bing liu xing nian biao=Chronology of epidemic diseases in ancient China. Fuzhou : Fujian ke xue ji shu chu ban she.

11. Zhang, D. D., Brecke, P., Lee H.F., He, Y-Q, \&Zhang, J. (2007) "Global climate change, war, and population decline in recent human history." Proceedings of the National Academy of Sciences, 104 (49) pp. 19214-19219. 